\title{
HOW MUCH DO PHONETIC REALISATIONS OF SERBIAN ACCENTS ACTUALLY DIFFER FROM EACH OTHER IN VARIOUS DIALECTS?***
}

In this paper, we wish to examine accent realisations in the regional dialects of the EastHerzegovinian dialect (E-H) and in the Srem regional dialects of the Vojvodina subdialect, which are dialectally and geographically closest to the E-H dialect but distinctly differ from it by specific accent realisation. We wanted to see whether falling and rising quality in accents of the analysed regional dialects required the same phonetic features as in other Neo-Štokavian regional dialects or if the inventory of these features was altered here. Also, we wished to determine whether realisations of the same accent in these regional dialects were the same or different, that is, whether phonetic features constituted one accent in two different dialects in an identical manner. The two short accents are most consistently distinguished by pitch relation between the accented vowel and the following one. The two dialects show more prominent differences in realisations of words with short rising accent. Although the analysed parameters of pitch and intensity mainly significantly differ from each other in the given regional dialects, those differences are not always perceptible.

Keywords: short rising accent, short falling accent, East-Herzegovinian dialect, Vojvodina subdialect, fundamental frequency, intensity.

\section{INTRODUCTION}

The accentual system of the standard Serbian language is based on the situation in the two most progressive Štokavian dialects: Šumadija-Vojvodina (hereinafter referred to as $\breve{S}-\mathrm{V}$ ) (ekavian in its essence) and East-Herzegovinian (hereinafter referred to as E-H) (ijekavian in its essence) (Subotić et al. 2012: 13). This accentual system comprises six prosodemes: four accented (which differ from each other by quantity and quality: long falling $\Gamma /$, long rising $/ /$, short falling $\Gamma /$ and short rising $/ /$ ) and two non-accented prosodemes, differing from each other by quantity: non-accented length $/ /$ and non-accented shortness $\Gamma /$. (Subotić et al.,

\footnotetext{
*dsredojevic@yahoo.com

** The present research was conducted as part of the project Digital media technologies, social and educational changes, funded by the Ministry of Education and Science of the Republic of Serbia.
} 
2012: 97). Dialectological descriptions state that the regional dialects of these two dialects mainly differ at the level of preservation of specific accentual alternations in the noun and pronoun-adjective declension and conjugation as well as preservation level of non-accented lengths (Ivić, 2001: 93-96, 176-177), showing that an older state of preservation, characterised by the valid accentual norm (set by Vuk and Daničić two centuries ago) is more evident in the regional dialects of the E-H dialect. Linguistically, in the east, in the territory of the $\breve{S}-\mathrm{V}$ dialect, this norm "softens" and is slightly altered and can be found in this form in the colloquial speech of educated speakers and in the speech of the most prestigious TV and radio stations in this region (Author 2009a; 2013). In addition, where the prosodic norm is concerned, the regional dialects of these two dialects differ from each other in terms of accent realisation as well (Ivić-Bošnjaković, \& Dragin 1994: 49). However, the already scarce phonetic literature in Serbian language linguistics hardly makes any record of this. In fact, the accent research conducted so far mainly covers realisations of accents in regional dialects from the $\breve{S}-\mathrm{V}$ dialect while examples from the E-H dialect are found merely symbolically. Since accent realisations in the regional dialects of these dialects do not sound exactly the same, we wished to review whether quality distinctions in the analysed regional dialects are based on the same phonetic features. In our aim to do this, we observed accent realisations in the regional dialects of the E-H dialect and in the Srem regional dialects of the Vojvodina subdialect, which are dialectally and geographically closest to the E-H dialect but distinctly differ from it by specific accent realisation. In other words, we wanted to see whether the falling and rising quality in accents of the analysed regional dialects requires the same phonetic features as in other NeoŠtokavian regional dialects or if the inventory of these features was altered here. Also, we wished to determine whether realisations of the same accent in these regional dialects were the same or different, that is, whether phonetic features constituted one accent in two different dialects in the identical manner. Since our scope of work does not allow us to analyse all accents, we decided to examine thoroughly short accents since the differences between them are "the subtlest" in our prosodic system, hardly detectable and acquirable in certain phonetic positions even by speakers living in the territory of our most progressive dialects (JokanovićMihajlov, 2007: 81; Petrović-Gudurić, 2010: 374). Data obtained in this research were compared with results of research conducted on the same dialects. 


\section{OVERVIEW OF PREVIOUS RESEARCH}

1. In the most famous phonetic and phonological research of Serbian accents conducted by Pavle Ivić and Ilse Lehiste half a century ago, most of the examples were demonstrated by Ivić himself, who spent a great portion of his life in Vojvodina as well as that of most of the twelve informers from an additional group whose speech was also being described (Ivić- Lehiste, 2002: 11, 171-172). Ivić’s examples of words with short falling accent in the medial sentence position are mainly characterised by falling pitch movement on the accented vowel (the pitch peak is close to the vowel half), falling pitch movement on the following vowel and falling pitch relation between these two vowels. Unlike in Ivić, rising pitch movement was recorded in a small number of informers from the additional group on the accented vowel while all the other phonetic features were identical to those of Ivić (Ivić-Lehiste, 2002: 18-21, 90-104). Ivić's realisations of words with short rising accent in the medial sentence position were mostly characterised by rising pitch movement on the accented vowel; rising pitch relation between this and the following vowel which had falling pitch movement. Realisations by informers from the additional group differed from those of Ivić in terms of pitch movement on the accented vowel. In fact, most often, the falling pitch movement on this vowel was recorded in their group and it was noted in $75 \%$ of examples of words with short falling accent. The authors concluded that the pitch movement on the accented vowel was phonologically irrelevant (Ivić-Lehiste, 2002: 25-29, 109-113). Although the intensity relation between the accented vowel and the following one is more falling in falling accents than in the rising ones, which may have the rising intensity relation - authors believe that in the analysed corpus, intensity does not have a systematic role in differentiating accents by quality (Ivić-Lehiste, 2002: 45, 78, 114-116).

2. While examining prosodic features of speech on the radio and television in the Belgrade area, Jelica Jokanović-Mihajlov found that speakers of Vojvodinian descent, who accented vowels in words with the short falling accent mainly had falling pitch movement which continued to the following vowel while the accented vowel of words with short rising accent might have rising movement which continued on to the next vowel (Jokanović-Mihajlov, 2007: 94). Still, in speaking of short accents, the author concludes that the fundamental realisation is a flat tone on the accented vowel and a phonologically relevant pitch of the following syllable which is higher in words with rising accents and lower in words with falling accents (Jokanović-Mihajlov, 2007: 78). When establishing the quality distinction, the author does not give great significance to intensity. 
3. In examining the prosodic features of the speech of Novi Sad, it was concluded that in the medial sentence position, the vowel with short falling accent mainly had rising pitch movement. There was a falling pitch relation between this and the following vowel and that the post-accentuated vowel had falling pitch movement (Sredojević, 2011a: 42-43) On the other hand, the accented vowel in words with a short rising accent mainly had falling pitch movement. There was a rising pitch interval between this and the following vowel (which could very often be rather large), while the post-accentuated vowel could have rising pitch movement (most commonly in two-syllable words) or rising-falling pitch movement with a more dominant falling interval (typical for three-syllable words) (Sredojević, 2009b; 2011a: 32-33). As far as intensity change is concerned, it was concluded that it did not have a systematic role in differentiating accents by quality (Sredojević, 2011a: 72-76).

4. Examining four Neo-Štokavian accents in professional speakers originating from Western Serbia and the ijekavian regional dialects of the EastHerzegovinian type, Jokanović-Mihajlov finds: "prominent pitch movement within the boundaries of accented syllables in all four accents; prominent intensity peak is on the accented syllable and longer in duration in a vowel under accent than of the vowel of the post-accentuated syllable" (Jokanović-Mihajlov, 2007: 60).

5. Examining accents in the speech of Novi Sad, the author also observed accent realisations in speakers from other speech areas, among them a speaker originating from the E-H dialect. Her realisations of words with short falling accent resembled the realisations of Novi Sad speakers although it was noticeable that between the accented vowel and the following one the falling interval was more prominent with this speaker. In words with a short rising accent, this speaker had the rising movement of the accented vowel (unlike speakers from Novi Sad) while the rising interval between this and the following vowel was less prominent than in the Novi Sad group (Sredojević, 2011a: 165).

\section{RESEARCH METHODS AND TECHNIQUES}

\section{Speakers}

The recording analysis results of thirteen final year students of journalism from the Faculty of Philosophy in Novi Sad (Table 1) are presented in this paper. Our speakers (hereinafter referred to as G1, G2... G13) originate from the territory of the Eastern Herzegovinian dialect (hereinafter referred to as the $1^{\text {st }}$ group) and from the territory of the regional dialects of Srem (referred to as the $2^{\text {nd }}$ group). All of them lived in their places of birth until they enrolled in the faculty in Novi Sad, 
where they spent three years. At the end of the seventh semester during which they attended lectures in diction, students presented a radio news assignment they had prepared themselves (accented and processed in terms of diction) and the recordings of those presentations served as the basis for this research. All news reports read by the students were written in the Serbian Ekavian variant.

The recording was performed in the Phonetic studio at the Faculty of Philosophy in Novi Sad, with the professional assistance of sound engineers. The reverberation period in the studio is $0.3 \mathrm{~s}$, which is sufficient for the authentic recording of speech. The material was digitally recorded with a sampling frequency of $44.1 \mathrm{kHz}$ and 16 bytes resolution. Sound Forge 8.0 and a Neumann U-67 microphone were used for the recording. Audiopenguin was used for audio recordings. The recorded material was processed by Praat, version 4.6.06 (Boersma-Weenink, 2017).

The Statistical Package for Social Sciences - SPSS 21 programme package was used in the statistical data analysis. For the comparison of values of numerical characteristics between two groups, the non-parametric test Mann-Whitney U was used. Values of the significance level with $p<0.05$ are regarded as statistically important.

\section{Corpus}

We analysed 90 words with short rising accent: demökratsku ('democratic') $(3)^{1}$, favòrizovanu ('favoured') (9), favorizovanu, izglèda ('seems') (7), izgleda (2), ko(n)kùrenata ('competitors'), konkùrenata, pòbēdi ('wins') (6), pòbedi (3), pöcetnom ('starting') (3), pòdsećaju ('they remind') (5), pòricao ('he denied') (7), pòsećaju [podsećaju] ('they remind'), primēte ('they notice') (7), primete, rekòrdēr ('record holder') (10), rèkordno ('record') (10), sùpärnicu ('female opponent') (8), sùparnicu, tèret ('burden') (4); and 48 words with short falling accent: bïtne ('essential') (11), ćüdo ('miracle') (2), čüdno ('strange') (3), döbila ('she got'), mèstimičnom ('partly') (2), nòvih ('new') (3), nòvog ('from new') (6), ösam ('eight') (2), pöčetom ('has been initiated') (4), prîmetno ('evidently'), prömene ('changes'), slìku ('image'), stärenje ('ageing'), vǐ̀se ('more') (4), znätno ('significantly') (6).

\footnotetext{
${ }^{1}$ The number of examples for each analysed word is given in the brackets.
} 
3. Analysed parameters

All recorded samples were carefully listened to and spectrograms and pitch contours were thoroughly analysed. Based on the analysis of the pitch contours, the values of the fundamental frequency (f0) were measured for every word: at the onset and the end of the accented vowel $\left(f 01_{o}, f 01_{e}\right)$ and at the onset of the first postaccentual vowel $\left(f 02_{o}\right)$, as well as the maximum $\mathrm{f} 0$ of the accented vowel $\left(f O 1_{\max }\right)$ and the first post-accentual vowel $\left(f O 2_{\max }\right)$. These values are expressed in Hertz $[\mathrm{Hz}]$. Based on these data, the pitch range between the onset and the end of accented vowel $R\left(f 01_{o}-f 01_{e}\right)$, the pitch range between pitch peaks of accented vowel and the following one $R\left(f 01_{\max }-f 02_{\max }\right)$, as well as the pitch range between the end of accented vowel and the onset of the following one $R\left(f 01_{e}-f 02_{o}\right)$ was calculated. The range values are expressed in semitones $(\mathrm{R}=$ $\left(12 \log _{10}\left(\mathrm{fO}_{2} / \mathrm{fO}_{1}\right)\right) / \log _{10} 2$ (Baken-Orlikoff 2000, 148)), which enables a reliable comparison of the results obtained from different speakers ('t Hart-Collier, \& Cohen, 2006: 24). Should, for example, the $\mathrm{fO}_{\mathrm{lo}}$ value be $119 \mathrm{~Hz}$, and $\mathrm{f}_{1 \mathrm{e}} 159 \mathrm{~Hz}$, this is described as the rising pitch movement and the pitch range between the onset and the end of that vowel is 5 semitones. On the other hand, if $\mathrm{fO}_{1 \mathrm{o}}$ is $159 \mathrm{~Hz}$, and $\mathrm{f}_{\mathrm{le}} 119 \mathrm{~Hz}$, this is falling pitch movement, and the pitch range between the onset and the end of that vowel is -5 semitones (Sredojević, 2017: 34-35).

Medium-intensity values on the accented vowel and the first post-accentual vowel $(I 1, I 2)$ were measured, and according to these, the difference in intensity between these two vowels was calculated $(I I-I 2)$. All values are expressed in decibels $[\mathrm{dB}]$.

By analysing the spectrograms and pitch contours, we determined the position of the pitch peak in the accented vowel. We measured the total duration of the accented vowel $(t 1)$, as well as the duration of the vowel from its onset to its pitch peak (t1max), and the values are expressed in milliseconds [ms]. Based on these data, the position of the pitch peak $\left(t 1_{\max \%}\right)$ was presented by the total duration of the accented vowel and is expressed in percentage. 
Table 1: Information on speakers

\begin{tabular}{cccccc}
\hline Initials & Mark & Place of birth & $\begin{array}{c}\text { Year of } \\
\text { birth }\end{array}$ & Gender & $\begin{array}{c}\text { Number of } \\
\text { examples }\end{array}$ \\
\hline P. K. & G1 & Bijeljina & 1992 & F & 15 \\
\hline G. T. & G2 & Pljevlja & 1991 & F & 15 \\
\hline Z. M. & G3 & Derventa & 1991 & F & 9 \\
\hline K. K. & G4 & Priboj & 1991 & F & 15 \\
\hline J. M. & G5 & Brčko & 1992 & M & 9 \\
\hline R. B. & G6 & $\begin{array}{c}\text { Bosanski Petrovac } \\
\text { / Sarajevo }\end{array}$ & 1993 & M & 4 \\
\hline D. N. & G7 & Vrdnik & 1991 & F & 9 \\
\hline P. N. & G8 & Ruma & 1991 & F & 14 \\
\hline S. M. & G9 & Vrdnik & 1991 & F & 8 \\
\hline R. N. & G10 & Ruma & 1992 & F & 13 \\
\hline M. J. & G11 & Ruma & 1991 & F & 10 \\
\hline K. I. & G13 & Ruma & 1991 & M & 13 \\
\hline & & & & &
\end{tabular}

\section{RESULTS AND DISCUSSION}

Table 2: Comparison of analysed parameters between the short falling and the short rising accents in the $1^{\text {st }}$ group ${ }^{2}$

\begin{tabular}{|c|c|c|c|c|c|c|c|}
\hline \multirow[b]{2}{*}{ Parameter } & & \multicolumn{2}{|c|}{ SF } & \multicolumn{2}{|c|}{ SR } & \multirow[b]{2}{*}{$\mathrm{U}$} & \multirow[b]{2}{*}{ sig. } \\
\hline & & $\overline{\mathrm{X}}$ & SD & $\bar{X}$ & SD & & \\
\hline$R\left(\mathrm{fO}_{1 \mathrm{o}}-\mathrm{fO}_{1 \mathrm{e}}\right)$ & & 0,31 & 1,45 & $-0,18$ & 1,14 & 338 & $p=0,036$ \\
\hline $\begin{array}{l}\mathrm{R} \quad\left(\mathrm{fO}_{1 \max }\right. \\
\left.\mathrm{fO}_{2 \max }\right)\end{array}$ & - & $-2,72$ & 2,16 & 1,63 & 1,09 & 2 & $\mathbf{p}=\mathbf{0 , 0 0 0}$ \\
\hline$R\left(\mathrm{fO}_{1 \mathrm{e}}-\mathrm{fO}_{2 \mathrm{o}}\right)$ & & $-2,25$ & 2,17 & 2,06 & 1,02 & 0 & $p=0,000$ \\
\hline $\mathrm{t} 1 \mathrm{max} \%$ & & 65,93 & 39,18 & 39,13 & 45,95 & 357 & $p=0,049$ \\
\hline $\mathrm{I} 1-\mathrm{I} 2$ & & 2,53 & 2,85 & 0,38 & 2,88 & 256,5 & $p=0,000$ \\
\hline
\end{tabular}

\footnotetext{
${ }^{2}$ Tables 2, 3, 4 i 5 for the given parameter provide data for: mean value $(\overline{\mathrm{X}})$ and standard deviation (SD), result of the Mann-Whitney $\mathrm{U}$ test (U) and p significance level (sig.). The value of the test which is statistically significant (for $p<0,05$ ) is written in bold letters in the tables.
} 
Table 3: Comparison of analysed parameters between the short falling and the short rising accents in the $2^{\text {nd }}$ group SF

SR

\begin{tabular}{lcccccc} 
Parameter & $\overline{\mathrm{X}}$ & $\mathrm{SD}$ & $\overline{\mathrm{X}}$ & $\mathrm{SD}$ & $\mathrm{U}$ & sig. \\
\hline $\mathrm{R}\left(\mathrm{fO}_{1 \mathrm{o}}-\mathrm{fO}_{1 \mathrm{e}}\right)$ & 1,23 & 1,50 & $-0,65$ & 1,54 & 203 & $\mathbf{p}=\mathbf{0 , 0 0 0}$ \\
\hline $\mathrm{R}\left(\mathrm{fO}_{1 \max }-\right.$ & $-2,72$ & 1,38 & 2,62 & 2,00 & 3 & $\mathbf{p}=\mathbf{0 , 0 0 0}$ \\
$\left.\mathrm{f} 0_{2 \max }\right)$ & & & & & & \\
\hline $\mathrm{R}\left(\mathrm{f} 0_{1 \mathrm{e}}-\mathrm{fO}_{2 \mathrm{o}}\right)$ & $-2,41$ & 1,56 & 2,93 & 1,72 & 0 & $\mathbf{p = 0 , 0 0 0}$ \\
\hline $\mathrm{t} 1 \mathrm{max} \%$ & 71,68 & 32,73 & 30,09 & 44,82 & 297 & $\mathbf{p}=\mathbf{0 , 0 0 0}$ \\
\hline $\mathrm{I} 1-\mathrm{I} 2$ & 3,77 & 3,23 & $-1,00$ & 2,14 & 98 & $\mathbf{p}=\mathbf{0 , 0 0 0}$ \\
\hline
\end{tabular}

Table 4: Comparison of analysed parameters in words with the short falling accent in the $1^{\text {st }}$ and the $2^{\text {nd }}$ group

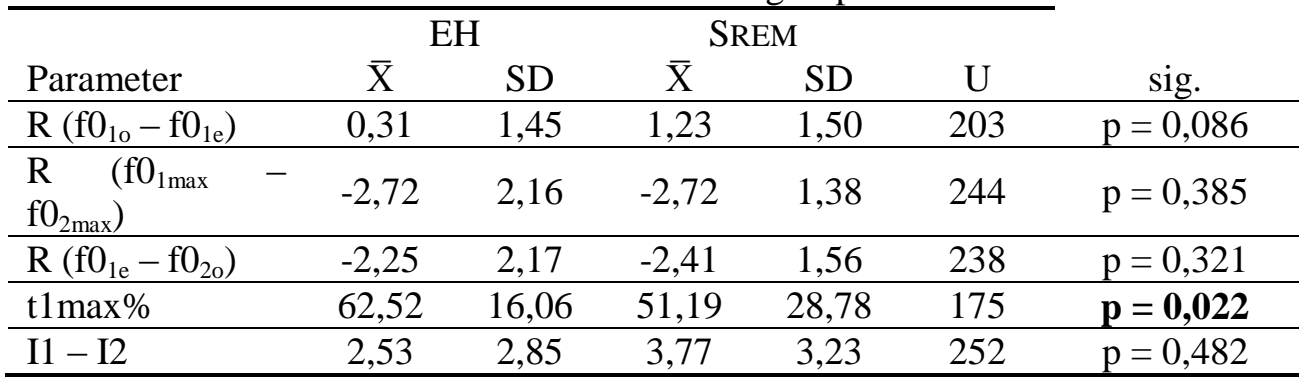

Tabela5: Comparison of analysed parameters in words with the short rising accent in the $1^{\text {st }}$ and the $2^{\text {nd }}$ group

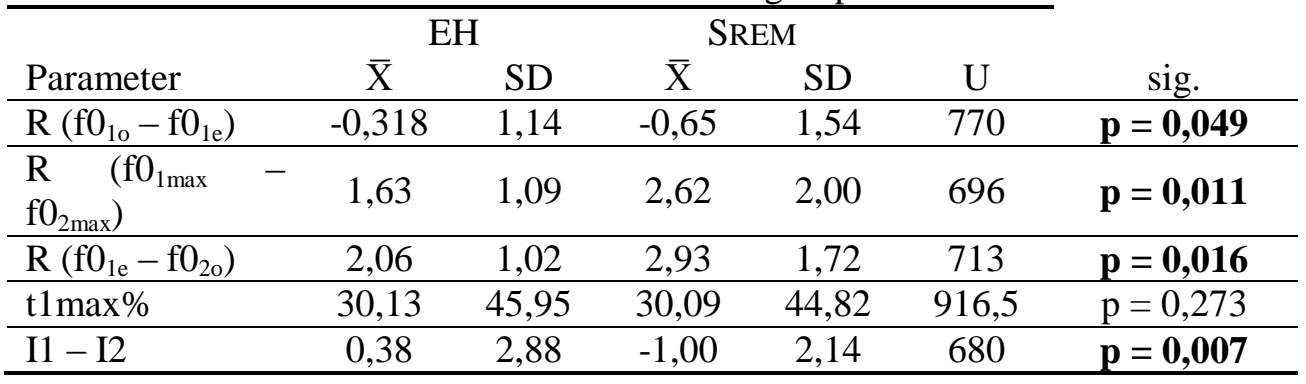

1. As can be seen from the data shown in tables 2 and 3, parameter $R\left(f O_{1 o}-\right.$ $f O_{l e}$ ), in both analysed groups, in words with short falling accent, the average value of $\mathrm{f0}$ at the end of the accented vowel is slightly higher than the average value of f0 at the onset of this vowel, while we have the opposite situation with words with short rising accent. The differences that do exist between two short accents are statistically significant in both analysed groups. However, it needs to be pointed out that the measured mean values of the pitch range between the onset and the end of 
the accented vowel are rather small and imperceptible (Rietveld-Gussenhoven, 1985: 304; Nootebom, 1997: 645). After thoroughly examining all material, we noticed that rising pitch movement on the accented vowels emerged mostly in words with short falling accent while the falling pitch movement mostly occurred with words with short rising accent. Since none of these pitch movements is present only with one short accent, it is clear that it has no phonological significance for establishing the quality distinction.

2. The data presented in tables 2 and 3, parameter $t 1$ max $\%$, show that in both analysed groups - in words with short falling accent - the pitch peak of the accented vowel is most commonly located in its second half while in the words with short rising accent the situation is quite opposite. Differences between two short accents are statistically significant in both analysed groups. However, we would like to stress that the position of the pitch peak in the first or the second half of the accented vowel is not exclusively the quality of either a rising or falling accent in any of the analysed speeches, which means that this phonetic feature is also not phonologically relevant for differentiating short accents.

3. After examining spectrograms of analysed samples from both groups, we concluded that in words with short falling accent there was a falling pitch relation between the accented vowel and the following vowel while in words with short rising accent, this pitch relation between the two vowels was rising. ${ }^{3}$ Those characteristics of the short accents can be seen in the data shown in tables 2 and 3 . In fact, two groups of words with accents of different quality statistically differ significantly in mean values of the pitch range between the end of accented vowel and the onset of the following vowel, parameter $R\left(f O_{l e}-f O_{2 o}\right)$, as well as in the mean values of the pitch range between the maximum f0 of these two vowels, parameter $R\left(f O_{1 \max }-f O_{2 \max }\right)$. Moreover, in all groups, the falling pitch relation between two observed vowels is consistently present in all samples with a short falling accent, while the rising pitch relation can be confirmed in all samples with a short rising accent.

The description of pitch features of short accents in the two analysed groups matches the descriptions recorded in the speech of Novi Sad (Sredojević, 2011a: 32-38, 42-45), while the conclusion attributing the phonological significance for establishing quality distinctions to the pitch relation between the accented vowel and the following one matches the conclusion made by other researchers (Ivić-Lehiste, 2002: 153-159; Sredojević, 2011a: 177-178).

\footnotetext{
${ }^{3}$ Examples in images 1 and 2 compare with examples in images 3 and 4 .
} 
4. As we can see from the data shown in tables 2 and 3, parameter $I 1-I 2$, in both analysed groups, in words with a short falling accent, between the accented vowel and the following one there is a distinct falling intensity relation which cannot be found in words with the short rising accent. The analysed data show that between two short accents, there are statistically significant differences in values of the parameter $I_{1}-I_{2}$. Although in more than $90 \%$ of the word samples with short falling accent in the $1^{\text {st }}$ group, that is, $81 \%$ of word samples from the $2^{\text {nd }}$ group, the accented vowel really had greater intensity than the following vowel. - this difference is not always perceptible. More precisely, in $14 \%$ of samples from the $1^{\text {st }}$ group and $18 \%$ of samples from the $2^{\text {nd }}$ group, the difference in intensity between the accented vowel and the following one was smaller than $1 \mathrm{~dB}$, and since it is the smallest intensity change we can detect as a change in loudness (Everest, 2001: 70), we hear those vowels as equally loud. On the other hand, a distinctly falling intensity relation is rarely found in words with a short rising accent. In these words, most commonly, a more dominant vowel in terms of intensity follows the accented one, but this difference is perceptible in only $22 \%$ of samples from the $1^{\text {st }}$ group and $47 \%$ of samples from $2^{\text {nd }}$ group. Since differences in intensity between the accented vowel and the following one in the examined speech are not always perceptible, it is clear that this parameter is not phonologically relevant for differentiating short rising and short falling accents.

Our findings regarding the intensity features of two vowels in words with short accents are mainly in line with the findings of other researchers (Ivić-Lehiste, 2002: 41-46; Sredojević, 2011a: 72-74).

5. As shown by the data presented in Table 4, words with a short falling accent, both in the $1^{\text {st }}$ and the $2^{\text {nd }}$ group, have identical pitch movement. ${ }^{4}$ The accented vowel mostly has the rising pitch movement. In all samples, there is the falling pitch relation between the accented vowel and the one following it and the first post-accentual vowel in all samples has the falling pitch movement. There is no statistically significant difference between the two groups of words according to any of the given parameters regarding pitch movement (Table 4) and the differences between the mean values are not perceptible. The given description entirely matches the description of this accent in the speech of Novi Sad (Sredojević, 2011a: 42-43), and in terms of some main features, it matches the description provided by Ivić and Lehiste (Ivić-Lehiste, 2002: 18-21; 90-104). In both examined groups, words with short falling accents are characterised by similar intensity relations. The intensity dominance of the accented vowel is noticeable in the $2^{\text {nd }}$ group. The

\footnotetext{
${ }^{4}$ Compare examples in image 1 and image 3 .
} 
difference in mean values of the $I I-I 2$ parameter in the two observed groups is perceptible but not statistically significant while the differences regarding the position of pitch peak are statistically significant but not perceptible. Otherwise stated, words with a short falling accent in the two analysed groups mostly have identical realisations and smaller differences, which do exist, but, most often, are not perceptible and mostly are not statistically significant.

6. Data presented in Table 5 show that in the two analysed groups - words with a short rising accent have very similar pitch movement. ${ }^{5}$ The accented vowel mainly has falling pitch movement. In all examples, there is the rising pitch relation between the accented vowel and the following one. Between the two groups of words there are statistically significant differences in all analysed parameters referring to pitch movement (Table 5). However, differences that do exist between mean values are not perceptible. Of course, between certain realisations of short rising accents in these dialects, there are perceptible differences and they are noticeable in examples from the $2^{\text {nd }}$ group where the pitch interval is more rising between two vowels than is the case in examples from the $1^{\text {st }}$ group. Pronounced pitch prominence of the post-accentuated vowel characterises many Vojvodinian regional dialects (Sredojević, 2011b: 390-391). In both analysed groups, the position of the pitch peak is almost identical. However, the two groups differ in mean values of the $I 1-I 2$ parameter. Intensity dominance of the post-accentuated vowel can be detected more often in examples from the $2^{\text {nd }}$ group, while in the examples from the $1^{\text {st }}$ group, these vowels are most commonly detected as identically loud or the accented vowel is louder. These results match the results of previous research of accents in the Novi Sad speech and in some regional dialects of the E-H dialect (Sredojević, 2011a; Sredojević, 2011), as well as conclusions regarding the incomplete process of Neo-Štokavian accent shift in speakers originating from Vojvodinian regional dialects, that is, the complete process in speakers originating from the E-H speech area (Jokanović Mihajlov, 2007).

\footnotetext{
${ }^{5}$ Compare examples in image 2 and image 4.
} 
Image 1: bî̀tne ('essential')

(G3, Derventa) ${ }^{6}$

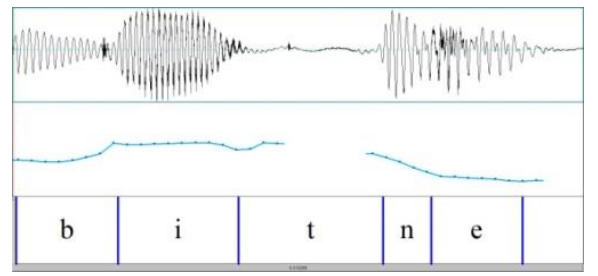

Image 3: pöčetom ('has been initiated')

(G10, Ruma)

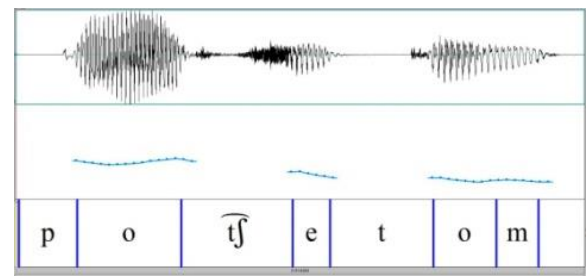

Image 2: pöbedi ('wins')

(G3, Derventa)

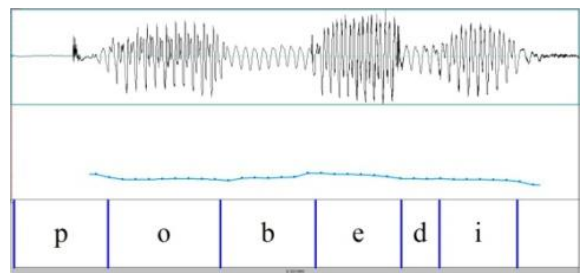

Image 4: izglèda ('seems')

(G8, Ruma)

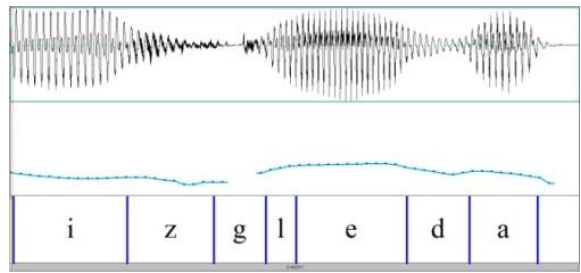

\section{CONCLUSION}

In order to determine the extent to which short accents in E-H and Srem regional dialects actually differ from each other and how much realisations of the same accent varies between them, we observed the parameters referring to the pitch movement and the position of pitch peak on the accented vowel in the analysed corpus, as well as the parameters referring to the pitch and intensity relations between this and the following vowel.

It is concluded that quality distinctions between accents in the given speeches were established by means of the same prosodic parameters. In those speeches, there are statistically significant differences in all analysed parameters between the two short accents. However, we have to point out the following: pitch movement which occurs on the accented vowel of words with short falling accent is sometimes also characterised by the accented vowel of words with short rising accent; the falling intensity relation between the accented vowel and the following one as well as the position of the pitch peak of the accented vowel in the second half of this vowel - are not the sole features of words with short falling accent, just

\footnotetext{
${ }^{6}$ Images shown in this paper contain oscillograms (in the upper part) and spectrograms (in the lower part). Symbols from the International Phonetic Alphabet (HIPA 2007) were used in transcription of examples.
} 
as the rising intensity relation and the moved pitch peak towards the onset of the vowel do not characterise all examples of words with short rising accent. Thus, we can conclude that such relations between acoustic features are actually accompanying phenomena of accents of certain quality but not its certain indicator.

In the given examples of these two dialects, the two short accents are most consistently distinguished by pitch relation between the accented vowel and the following one - both between their pitch peaks and between the end of one and the onset of the next vowel. The results of our research match the results of previous research of Serbian accents (Ivić-Lehiste, 2002: 153-159; Sredojević, 2011a: 177178).

Unlike previous studies, this one shows how similar realisations of short accents in two different dialects actually are and what these similarities rest on. Words with short falling accent in the analysed speeches mostly have similar realisations. The existing differences are most commonly neither perceptible nor statistically significant. The two dialects show more prominent differences in the realisations of words with short rising accent. Although the analysed parameters of pitch and intensity mainly statistically differ from each other significantly in the given dialects, those differences are not always perceptible. In some examples, those differences are perceptible and supported by the fact that there is a more rising pitch and intensity relation in the Srem regional dialects between the accented vowel and the following one than is the case in examples from the E-H dialect.

\title{
Dejan Sredojević \\ KOLIKO SE ZAPRAVO FONETSKE REALIZACIJE SRSPKIH AKCENATA MEĐUSOBNO RAZLIKUJU U DIJALEKTIMA?
}

\begin{abstract}
Sažetak
$\mathrm{U}$ ovom istraživanju želeli smo da ispitamo realizacije akcenata $\mathrm{u}$ govorima istočnohercegovačkog dijalekta i u sremskim govorima vojvođanskog poddijalekta, koji dijalekatski i geografski gledano stoje najbliže IH dijalektu, ali se od njega jasno razlikuju specifičnom realizacijom akcenata. Drugim rečima, zanimalo nas je da li se u posmatranim govorima za uzlanost i silaznost kod akcenata koriste iste fonetske karakteristike kao i u drugim novoštokavskim govorima ili je inventar tih karakteristika ovde izmenjen. Takođe, želeli smo da utvrdimo i da li su realizacije istog akcenta u ovim govorima iste ili različite, odnosno da li fonetske karakteristike na identičan način konstituišu jedan akcenat u dvama različitim diajlektima. Kako nam obim rada nije dozvoljavao da posmatramo sve akcente, odlučili smo se za detaljnu analizu kratkih akcenata. Analizirano je 138 primera reči s kratkim akcentima, koje je realizovalo trinaestoro govornika. Posmatrani su akustički parametri: raspon f0 (između početka i kraja naglašenog vokala, između kraja naglašenog i početka narednog vokala, između tonskih vrhunaca ovih dvaju vokala), kao i razlika
\end{abstract}


intenziteta između ovih dvaju vokala i određeni parametri trajanja. Utvrđeno je da se kvalitetske distinkcije između akcenata u posmatranim govorima uspostavljaju uz pomoć istih prozodijskih parametara. U posmatranim primerima iz dvaju govora dva kratka akcenta najdoslednije razlikuje tonski odnos između naglašenog i narednog vokala - kako između njihovih tonskih vrhunaca, tako i između kraja jednog i početka drugog vokala. Reči sa kratkosilaznim akcentom u posmatranim govorima uglavnom imaju približno slične realizacije. Dva govora se izrazitije razlikuju u realizacijama reči sa kratkouzlaznim akcentom. Iako se posmatrani parametri tona i intenziteta uglavnom statistički značajno razlikuju u posmatranim govorima, te razlike nisu uvek perceptibilne.

Ključne reči: kratkouzlazi akcenat, kratkosilazni akcenat, istočnohercegovački dijalekat, vojvođanski poddijalkat, učestalost, intenzitet

\section{REFERENCES}

Baken, R. J.-Orlikoff, R. F. (2000). Clinical Measurement of Speech and Voice $\left(^{\text {nd }}\right.$ Edition). San Diego: Singular Thomson Learning.

Boersma, P. \& Weenink, D. (2011). Praat: doing phonetics by computer (Version 5.2.28) [Computer program]. Retrieved 28 June 2017 from http://www.praat.

org.

Everest, F. A. $\left(2001^{4}\right)$. Master Handbook of Acoustics. New York: McGraw-Hill. Ivić P.-Bošnjaković, Ž. \& Dragin, G. (1994). Banatski govori šumadijskovojvođanskog dijalekta. Knj. 1, Uvod i fonetizam. Srpski dijalektološki zbornik, XL, 1-419.

Ivić, P. (2001). Dijalektologija srpskohrvatskog jezika: uvod i štokavsko narečje. Sremski Karlovci - Novi Sad: Izdavačka knjižarnica Zorana Stojanovića.

Ivić, P.-Lehiste, I. (2002). O srpskohrvatskim akcentima. Sremski Karlovci - Novi Sad: Izdavačka knjižarnica Zorana Stojanovića.

Jokanović-Mihajlov, J. (2007). Akcenat i intonacija govora na radiju i televiziji. Beograd: Društvo za srpski jezik i književnost Srbije.

Nootebom, S. (1997). The Prosody of Speech: Melody and Rhythm. In: Hardcastle,

W. J.- Laver, J. (Eds.). The Handbook of Phonetic Sciences. Oxford: Basil Blackwell Limited. 640-673.

Petrović, D.-Gudurić, S. (2010). Fonologija srpkoga jezika, Beograd - Novi Sad: SANU. Institut za srpski jezik - Beogradska knjiga - Matica srpska.

Rietveld, A.C.M.-Gussenhoven, C. (1985). On the Relation between Pitch Excursion Size and Pitch Prominence. Journal of Phonetics, 13, 299-308.

Sredojević, D. (2009a). Akcenat imenica u jeziku voditelja-spikera novosadskih televizijskih stanica. U: Bošnjaković, Ž. (ur.). Govor Novog Sada. Sv. 1, 
Fonetske osobine. Novi Sad: Filozofski fakultet, Odsek za srpski jezik i lingvistiku. 215-234.

Sredojević, D. (2009b). Eksperimentalno-fonetsko ispitivanje kratkouzlaznog akcenta u novosadskom govoru - tonska komponenta. U: Bošnjaković, Ž. (ur.). Govor Novog Sada. Sv. 1, Fonetske osobine. Novi Sad: Filozofski fakultet, Odsek za srpski jezik i lingvistiku. 159-191.

Sredojević, D. (2011a). Eksperimentalno-fonetsko ispitivanje prozodijskih karakteristika novosadskog govora. [doktorska disertacija]. Novi Sad: Filozofski fakultet.

Sredojević, D. (2011b). Prepoznavanje novosadskog izgovora i stavovi prema njemu. U Vasić, V.- Gordana, Š. (ur.), Govor Novog Sada. Sv. 2, Morfosintaksičke, leksičke i pragmatičke osobine. Novi Sad: Filozofski fakultet, Odsek za srpski jezik i lingvistiku. 378-398.

Sredojević, D. (2011). Dugouzlazni akcenat u novosadskom govoru: fonetske karakteristike i fonološka interpretacija. Zbornik Matice srpske za filologiju i lingvistiku, LIV/2, 108-133.

Sredojević, D. (2013). Neakcentovane dužine i jezik medija. U: Krčmar, V. (ur.). Zbornik radova Akademije umetnosti. Novi Sad: Akademija umetnosti. 205-224.

Subotić, Lj. Sredojević, D. Bjelaković, I. (2012). Fonetika i fonologija: ortoepska $i$ ortografska norma standardnog srpskog jezika [Elektronski izvor]. Novi Sad: Filozofski fakultet.

Sredojević, D. (2017). Fonetsko-fonološki opis akcenata u standardnom srpskom jeziku - od specifičnog ka opštem. Novi Sad: Filozofski fakultet.

't Hart, J.-Collier, R. \& Cohen, A. (2006). A Perceptual Study of Intonation: An Experimental-Phonetic Approach to Speech Melody. Cambridge University Press. 